\title{
Influence of Foliar Application by EM "Effective Microorganisms", Amino Acids and Yeast on Growth, Yield and Quality of Two Cultivars of Onion Plants under Newly Reclaimed Soil
}

\author{
Z. F. Fawzy ${ }^{1}$, Abou El-magd M. M. ${ }^{1}$, Yunsheng $\mathrm{Li}^{2}$, Zhu Ouyang ${ }^{2}$ \& A. M. Hoda ${ }^{1}$ \\ ${ }^{1}$ Vegetable Research Dept., National Research Centre, Dokki, Cairo, Egypt \\ ${ }^{2}$ Yucheng Comprehensive Experimental Station, Key Laboratory of Ecosystem Network Observation and \\ Modeling, Institute of Geographic Sciences and Natural Resources Research, Chinese Academy of Sciences, \\ China \\ Correspondence: Yunsheng Li, Yucheng Comprehensive Experimental Station, Key Laboratory of Ecosystem \\ Network Observation and Modeling, Institute of Geographic Sciences and Natural Resources Research, Chinese \\ Academy of Sciences, China. E-mail: liys@igsnrr.ac.cn
}

Received: June 21, 2012 Accepted: July 17, 2012 Online Published: October 12, 2012

doi:10.5539/jas.v4n11p26

URL: http://dx.doi.org/ doi:10.5539/jas.v4n11p26

This research was funded by the key project of IGSNRR, CAS, grant number: $2012 S J 003$

\begin{abstract}
Two field experiments were carried out in two successive seasons of 2009/2010 and 2010/2011 in newly reclaimed soil at Wady Elmollak, Ismailia Governorate, Egypt to study response of two varieties of onion plant "Giza 20 and Super X" of foliar spraying of EM "Effective microorganisms", amino acids and yeast on growth, and its quality as well as chemical composition. Results showed that Giza $20 \mathrm{cv}$ gave the highest amount of vegetative growth "plant height and fresh weight of leaves" in the two seasons. Whilst, Super X cv. gave the highest amount of fresh weight of bulbs and whole plants. Moreover, using Super X cv gave the highest yield and quality on onion. Furthermore, Giza $20 \mathrm{cv}$. gave the highest amount of T.S.S, N, P and K\% as well as some trace elements compared with Super $\mathrm{X} \mathrm{cv}$. With regard to foliar application treatments, the results indicated that, using EM, amino acids and yeast had positive promoting effects by providing supplemental doses of these components on growth, yield and its quality as well as all chemical composition compared with control plants. It may be concluded that using yeast at rates of $3 \mathrm{gm}$./L gives the highest growth parameters. However, using EM at rates of $3 \mathrm{~cm} / \mathrm{L}$ gives the highest yield and its quality of onion plants. Generally, it can be found that, using Super X cv. with foliar spraying of EM give the highest amount of growth, yield and quality of onion plants.
\end{abstract}

Keywords: onion, EM "effective microorganism", amino acids, yeast, cultivars, growth, yield, chemical composition

\section{Introduction}

Onion (Allium cepa L.) is an important bulb crop grown worldwide. It is an important crop in all condiment and used of flavouring the food, both at mature and immature bulb stages besides being used as salad and pickles. To lesser extent, it is used by processing industry for dehydration in the form of onion flakes and powder, which are in great demand in the world market. The great advances in techniques and methods of production of this crop in Egypt during the last decade perhaps open enormous pathways for exportation. Thus, the present work has involved studies on foliar application onion with EM (effective microorganisms) amino green and yeast because it is well known that this kind of treatments for obtaining clean and safe product.

Farmers have adopted the strategy of increasing crop yields by applying large amounts of chemical fertilizers and pesticides. At present, however, the negative effects of heavy applications of chemical inputs, in terms of production, environment, and quality deterioration are becoming apparent (Nishio, 1996). The ultimate goal of sustainable agriculture is to develop farming systems that are productive, profitable, energy-conserving, environmentally-sound, conserving of natural resources such as soil and water, and that ensure food safety and quality. 
The cultivars genotype plays an important role of growth, yield and quality on onion plants (Mostafa, 1998; Daiz, 1994; Mohanty, 2001; Rahmanet al., 2002; Leilahet al., 2003; Gomaa, 2006; Haydar et al., 2007).

Microbial fertilizer is one way that organic farmers are able to increase yield and quality of crops without a large investment of money and labor (Pham, 2004). Moreover, microbial fertilizer can clean the environment and encourage the productive capacity of land by reducing the amount of chemical fertilizer consumption (Pham, 2004).

Various effective microorganisms and physiological active substances are contained in EM. Therefore, it must be effective to improve the quality and productivity of soil and to increase the vegetable production (Higa, 1991). In general, the vegetable crops require many nutrients for short period of cultivation. It seems that EM is a good supply source of nutrients in vegetable crops, because EM can make a favorable condition for the growth of crops, promoting the mobilization of non-soluble and activating the beneficial microorganisms in soil (Higa,. 1991, 2000; Hussain et al., 2002). Application of EM is known to enhance crop growth and yield in many vegetable crops (Kengo \& Hui-lian, 2000; Sheng \& Lian, 2002; Javaid, 2006, 2009; Khaliq et al., 2006; Daiss et al., 2008; Javaid \& Nasir, 2010).

The requirement of amino acids in essential quantities is well known as a means to increase yield and overall quality of corps (Sanaa, et al., 2001; Slviero et al., 2001; Attoa et al., 2002; El- Shabasi et al., 2005; Awad et al., 2007; Fawzy, 2007; Al-Said \& Kamal, 2008; Faten et al., 2010; Fawzy et al, 2010; Shaheen et al., 2010).

Dry yeast is a natural bio-substance suggested to be of useful stimulatory, nutritional and protective functions when it is applied on to vegetable plants during stressful condition due to its hormones, sugars, amino and nucleic acids, vitamins and minerals. The dry bread yeast (Saccharomyces cerevisiae) is a kind of the used biofertilizers in soil fertilization or in foliar application on the shoots of vegetable crops (El-Ghamriny et al., 1999). This is because it's content of many nutrient elements and being productive compounds of semi growth regulator compounds like auxins, gibberellins and cytokinins (Glick, 1995). Glick recorded that the yeast was capable of increasing the simulative growth compounds like gibberellins, auxins and cytokinins that act in improving plant cell division and growth. Foliar application of yeast was found to increase growth, yield and quality of many vegetable crops (Abou El-Nasr et al., 2001; Gomaa et al., 2005, Mona et al., 2005; El-Tohamy \& El-Greadly, 2007; El-Tohamy et al., 2008, Fawzy, 2007; Hussain \& Khalaf, 2007; Fawzy et al., 2010; Ghoname et al., 2010).

The aim of present study was to evaluate the efficiency of foliar application of EM, active yeast extract and amino acids on improving onion growth, productivity and bulbs quality.

\section{Material and Methods}

Two successive field experiments were carried out on onion (Allium cepa, L.) in newly reclaimed soil at Wady Elmollak, Ismailia Governorate, Egypt during 2009/2010 and 2010/2011 seasons to study response of two varieties of onion plant growth, yield and quality to foliar nutrients. Seeds of onion cvs. Giza 20 and Super X were sown in the nursery on $15^{\text {th }}$ and $7^{\text {th }}$ of October in 2009 and 2010 seasons, respectively. All required agricultural managements for seedling production were carried out. Seedling was transplanted in the field after 45 days.

The experimental design was split plot with three replicates. Varieties of onion accepted the main plot and treatments of foliar nutrients were randomly allocated in the sub plots. Each experiment included twenty treatments representing the interaction between two varieties of onion i.e., Giza 20 and Super X with ten rates of foliar nutrients as follows:

* Control (Spray with tap water).

* Foliar spray of EM = Effective microorganism, at three rates $(1 \mathrm{~cm} / \mathrm{L}, 2 \mathrm{~cm} / \mathrm{L}$ and $3 \mathrm{~cm} / \mathrm{L})$.

EM solution consists of useful micro-organisms and it safe for plants and soil. EM consists of photosynthesis bacteria, lactic acid bacteria and yeast. An EM effective microorganism is bio-fertilizer was got from Ministry of Egyptian Agriculture.

* Foliar spray of amino green II compound at three rates $(1 \mathrm{~cm} / \mathrm{L}, 2 \mathrm{~cm} / \mathrm{L}$ and $3 \mathrm{~cm} / \mathrm{L}$.

Amino green compound contains (w/v) total organic acids plus amino acids $15 \%$, iron (Fe), $2.9 \%$, Zinc ( $\mathrm{Zn})$ $1.4 \%$ and Manganese (Mn) $0.7 \%$. Free amino acids, proline, Hydroxyl proline, Glysine, Alanine, Faline, Methionine, Escoliosin, Lyosine, Cyctin, Finel Alanin, Syrin, Glotomic) Arjenin, Hydroxy, Lysing and Hystiden. (Compound contain organic and amino acids and trace elements was got at from Dishner company for chemicals and trading, Giza- Egypt). 
* Active dry yeast was used at three rates $(1 \mathrm{gm} . / \mathrm{L} ., 2 \mathrm{gm}$. $/ \mathrm{L}$., and $3 \mathrm{gm} . / \mathrm{L})$

The analysis of dry yeast was protein (47.2 \%), Arginine (2.6\%), Glycin (2.6\%), Histidine (1.4\%), Esoloysine (2.9\%), Leucine (3.5\%), Lycine (3.8 \%), Mehioninecystine (0.6\%), Phenyl-alanine (3\%), Tryptophan (0.5 \%) and vitamin B (2.9 \%) (N. R. P. 1977), Goyal and Khuller (1992), Yatskovskaya et al. (1992), Ahmed et al. (1997) and Khedr and Farid (2002) reported that yeast preparation contained carbohydrates, sugars, hormones, macro and micro elements in suitable balance.

Plants were sprayed with dry yeast, amino green compound and EM solution every week after month of transplanting for two month.

\section{Data recorded:}

A. Vegetative growth: five plants from each plot were chosen randomly 120 days after transplanting for measuring the following characters:

1. Plant height $(\mathrm{cm})$.

2. Leaves number/ plant.

3. Bulb diameter $(\mathrm{cm})$.

4. Neck diameter $(\mathrm{cm})$.

5. Bulbing ratio

6. Fresh weight of plant and its organs (leaves and bulbs).

B. Yield: total yield of onion was recorded per feddan.

C. Bulb quality: weight and diameter of bulbs at harvesting were recorded.

Total soluble solids (T.S.S) were assayed according to A.O.A.C (1990). Total nitrogen and phosphorus contents were determined using Kieldahl method and colorimetric method using spectrophotometer (SPECTRONIC 20D, Milton Roy Co. Ltd., USA), according to the procedure described by Cottenie (1980). Potassium content was measured using flame photometer method (JENWAY, PFP-7, ELE Instrument Co. Ltd., UK) as described by Chapman and Pratt (1982).

Copper, Zinc, Iron and Magnesium were determined using the Atomic Absorption Spectrophotometer (Philips) according the methods described by Chapman and Pratt (1961).

The obtained data were subjected to the analysis of variance procedure and mean were compared using the L.S.D. method at $5 \%$ level of significance according to Gomez and Gomez (1984).

\section{Results and Discussion}

\subsection{Vegetative Growth}

\subsubsection{Effect of Varieties}

Vegetative characters of onion plant expressed as plant height, leaf numbers, fresh weight of leaves, bulbs and total plant were statistically affected by varieties of onion plants (Table 1). The differences resulting by the varieties reached the level of significant at all vegetative growth characters in the two seasons of study except for number of leaves in the second seasons. In addition, the highest values in vegetative growth were obtained by the Giza $20 \mathrm{cv}$. except for fresh weight of bulb. On the other hand, the lowest values of plant growth (plant height, leaf number and fresh weight of leaves) were recorded by Super X cv. The observed differences in vegetative growth of cultivars are mainly due to the genotype of each cultivar. The observed differences in vegetative growth of cultivars are mainly due to the genotype of each cultivar. This result was in harmony with previous findings (Daiz, 1994; Mohanty, 2001; Rahman et al., 2002; Haydar et al., 2007).

Table 1. Effect of two varieties of onion on vegetative growth characters in the 2009/2010 and 2010/2011 seasons

\begin{tabular}{|c|c|c|c|c|c|c|c|c|c|c|}
\hline \multirow[t]{2}{*}{ Varieties } & \multirow{2}{*}{$\begin{array}{l}\text { Plant } \\
\text { height }(\mathrm{cm})\end{array}$} & \multirow{2}{*}{$\begin{array}{l}\text { Leaf } \\
\text { No./plant }\end{array}$} & \multicolumn{3}{|c|}{ Fresh weight(gm.) } & \multirow[t]{2}{*}{ Plant height $(\mathrm{cm})$} & \multirow{2}{*}{$\begin{array}{l}\text { Leaf No./plant } \\
\text { Bulbs }\end{array}$} & \multicolumn{3}{|c|}{ Fresh weight(gm.) } \\
\hline & & & Leaves & Bulbs & Total & & & Leaves & Bulbs & Total \\
\hline Giza 20 & 51.23 & 9.40 & 32.87 & 100.60 & 133.49 & 42.16 & 6.59 & 31.88 & 108.34 & 140.22 \\
\hline Super X & 42.16 & 6.82 & 13.34 & 123.42 & 136.45 & 41.23 & 6.73 & 13.00 & 132.28 & 145.28 \\
\hline L.S.D at 0.05 & 0.66 & 0.56 & 1.71 & 7.65 & 0.08 & 0.23 & NS & 4.45 & 11.49 & 0.03 \\
\hline
\end{tabular}

3.1.2 Effect of Foliar Application 
Data in Table 2 shows clearly that foliar application of EM, amino green and yeast have a significant effect on the vegetative growth characterizes of onion plant in the two seasons of study. The increments were gradually and consistently with increasing the levels of yeast $1 \mathrm{gm}$. to $3 \mathrm{gm}$. /L. Generally, it could be concluded that, the highest values of plant height, number of leaves and fresh weight of onion plants were recorded by using yeast at rates of $3 \mathrm{gm}$. /L. compared with other treatments. On the contrary, the lowest values of vegetative growth of onion plants recorded by control plants (foliar spray with water). These findings were true in both seasons. These increments with using yeast as a foliar spray might be attributed to the effect of yeast extract in increasing levels of endogenous hormones in treated plants which could be interpreted to cell elongation and cell division (Khedr and Faried, 2002). Also, these results may be due to the physiological roles of vitamins and amino acids in the yeast extract which increased the metabolic processes rate and levels of indigenous hormones, i.e. LAA and $\mathrm{GA}_{3}$ (Chailakhyn, 1957; N.R.P., 1977).

Table 2. Effect of foliar application of EM" Effective microorganisms", amino green (AG) and yeast on vegetative growth characters of onion plants in the 2009/2010 and 2010/2011 seasons

\begin{tabular}{|c|c|c|c|c|c|c|c|c|c|c|}
\hline \multirow[t]{2}{*}{ Treatments } & \multirow{2}{*}{$\begin{array}{l}\text { Plant } \\
\text { height }(\mathrm{cm})\end{array}$} & \multirow{2}{*}{$\begin{array}{l}\text { Leaf } \\
\text { No./plant }\end{array}$} & \multicolumn{3}{|c|}{ Fresh weight(gm.) } & \multirow{2}{*}{$\begin{array}{l}\text { Plant } \\
\text { Height } \\
(\mathrm{cm})\end{array}$} & \multirow{2}{*}{$\begin{array}{l}\text { Leaf } \\
\text { No./plant }\end{array}$} & \multicolumn{3}{|c|}{ Fresh weight(gm.) } \\
\hline & & & Leaves & Bulbs & Total & & & Leaves & Bulbs & Total \\
\hline Control & 36.08 & 6.25 & 8.19 & 45.08 & 53.27 & 35.83 & 5.27 & 10.30 & 50.95 & 61.25 \\
\hline EM 1 & 45.37 & 7.67 & 21.80 & 101.93 & 123.73 & 42.38 & 6.50 & 22.34 & 108.42 & 130.76 \\
\hline EM2 & 49.37 & 9.08 & 26.28 & 129.14 & 155.73 & 45.58 & 7.17 & 21.43 & 139.47 & 160.90 \\
\hline EM 3 & 47.78 & 8.83 & 31.49 & 159.33 & 187.82 & 40.72 & 7.50 & 32.63 & 162.74 & 195.37 \\
\hline AG 1 & 45.33 & 7.50 & 18.06 & 91.26 & 109.32 & 42.00 & 6.17 & 19.73 & 98.67 & 118.40 \\
\hline AG 2 & 49.25 & 8.25 & 22.88 & 111.86 & 134.74 & 45.33 & 6.08 & 23.09 & 120.65 & 143.74 \\
\hline AG 3 & 46.16 & 8.08 & 27.59 & 106.27 & 133.86 & 36.05 & 6.83 & 28.42 & 116.32 & 144.74 \\
\hline Yeast 1 & 48.48 & 7.33 & 18.26 & 90.46 & 108.72 & 40.87 & 6.42 & 19.10 & 98.86 & 117.96 \\
\hline Yeast 2 & 48.42 & 8.25 & 24.35 & 130.16 & 154.52 & 42.00 & 6.83 & 24.33 & 140.67 & 165.00 \\
\hline Yeast 3 & 50.60 & 9.83 & 32.28 & 156.08 & 188.36 & 45.58 & 7.83 & 32.99 & 166.35 & 199.34 \\
\hline L.S.D at 0.05 & 2.95 & 1.84 & 7.72 & 30.93 & 34.72 & 3.04 & 1.08 & 9.32 & 30.92 & 22.34 \\
\hline
\end{tabular}

\subsubsection{Effect of the Interaction}

The interaction effect within varieties of onion plants and foliar application treatments on vegetative characters of onion plant expressed as plant height leaves number, fresh weight of leaves, bulbs and total plant of onion plants shown in Table 3. There were significant differences in the all vegetative growth parameters in the first season except for number of leave parameter. Whilst, there were no significant effect in the all vegetative growth parameters in the second season except for total fresh weight of whole onion plant. Moreover, the highest plant height was recorded by Giza $20 \mathrm{cv}$. and foliar spray with yeast at a rate of $1 \mathrm{gm}$. /L in the first season and by Giza $20 \mathrm{cv}$. with foliar spray of yeast at rates of $3 \mathrm{gm}$. / L in the second one. On the contrary, the lowest value of plant height was found by Giza $20 \mathrm{cv}$. with foliar spray of water in the first season and by Super X cv. with control treatment (foliar spray with water) in the second season. With regard of number of leaves, data in Table 3 show that, the highest amount number of leaves was recorded by using Giza $20 \mathrm{cv}$ with foliar spray of yeast at a rate of $3 \mathrm{gm}$. /L in the first season and by Super X cv and foliar spray of EM at rates of $3 \mathrm{~cm} / \mathrm{L}$ in the second season. On the other hand, the lowest amount of number of leaves was found by Super X cv. and foliar spray of water in the first season and with Giza $20 \mathrm{cv}$. and foliar spray with water in the second season, respectively. However, the highest fresh weight of leaves was recorded by Giza $20 \mathrm{cv}$. with foliar spray of yeast at rates of 3 $\mathrm{gm}$. /L in the first season, whilst, by using Giza $20 \mathrm{cv}$ with foliar spray of AG at rates of $3 \mathrm{~cm} / \mathrm{L}$ in the second one. On the contrary, the lowest values were recorded by Super X cv. with foliar spray of water. These findings were true in both seasons. Moreover, data in Table 3 demonstrated that, the highest fresh weight of bulb and whole plants were recorded by using Super X cv. with foliar spray of EM at rates of $3 \mathrm{~cm} / \mathrm{L}$. On the other hand, the lowest values were found by Giza $20 \mathrm{cv}$. with foliar spray with water. These findings were true in both growing seasons. 
Table 3. Effect of the interaction between varieties and foliar application of EM-Effective microorganisms, amino green (AG) and yeast on vegetative growth characters of onion plants in the 2009/2010 and 2010/2011 seasons

\begin{tabular}{|c|c|c|c|c|c|c|c|c|c|c|c|}
\hline \multirow[t]{5}{*}{ Varieties } & \multirow[t]{2}{*}{ Treatments } & \multirow{2}{*}{$\begin{array}{l}\text { Plant } \\
\text { height }(\mathrm{cm})\end{array}$} & \multirow{2}{*}{$\begin{array}{l}\text { Leaf } \\
\text { No./plant }\end{array}$} & \multicolumn{3}{|c|}{ Fresh weight(gm) } & \multirow{2}{*}{$\begin{array}{l}\text { Plant } \\
\text { height }(\mathrm{cm})\end{array}$} & \multirow{2}{*}{$\begin{array}{l}\text { Leaf } \\
\text { No./plant }\end{array}$} & \multicolumn{3}{|c|}{ Fresh weight(gm) } \\
\hline & & & & Leaves & Bulbs & Total & & & Leaves & Bulbs & Total \\
\hline & Control & 35.83 & 7.00 & 10.01 & 27.93 & 37.93 & 36.33 & 4.87 & 11.61 & 28.46 & 40.07 \\
\hline & EM 1 & 47.68 & 8.33 & 31.78 & 102.76 & 134.55 & 43.05 & 6.67 & 31.13 & 107.43 & 138.56 \\
\hline & EM2 & 52.57 & 11.00 & 35.69 & 89.75 & 125.44 & 46.62 & 6.83 & 25.03 & 100.42 & 125.45 \\
\hline \multirow[t]{11}{*}{ Giza 20} & EM 3 & 54.83 & 9.33 & 40.08 & 113.53 & 153.61 & 40.72 & 7.67 & 41.55 & 119.82 & 161.37 \\
\hline & AG 1 & 48.15 & 9.67 & 24.97 & 73.88 & 98.84 & 42.50 & 6.17 & 25.77 & 82.34 & 108.11 \\
\hline & AG 2 & 52.42 & 10.50 & 34.14 & 102.40 & 136.55 & 46.08 & 5.83 & 33.52 & 110.98 & 144.50 \\
\hline & AG 3 & 55.50 & 9.50 & 45.96 & 151.40 & 196.99 & 36.82 & 6.83 & 45.22 & 161.03 & 206.25 \\
\hline & Yeast 1 & 56.08 & 8.33 & 26.61 & 88.99 & 115.60 & 40.87 & 6.50 & 26.31 & 97.21 & 123.52 \\
\hline & Yeast 2 & 54.17 & 9.50 & 35.36 & 125.34 & 160.70 & 42.67 & 7.00 & 35.08 & 135.34 & 170.42 \\
\hline & Yeast 3 & 55.03 & 11.83 & 44.34 & 130.37 & 174.72 & 46.16 & 7.50 & 43.54 & 140.37 & 183.91 \\
\hline & Control & 36.33 & 5.50 & 6.37 & 62.24 & 68.60 & 35.33 & 5.67 & 8.98 & 73.44 & 82.42 \\
\hline & EM 1 & 43.05 & 7.00 & 11.81 & 101.10 & 112.91 & 41.72 & 6.33 & 13.54 & 109.40 & 122.94 \\
\hline & EM2 & 46.42 & 7.17 & 16.86 & 168.52 & 185.38 & 44.75 & 7.50 & 17.84 & 178.52 & 196.36 \\
\hline & EM 3 & 40.72 & 8.33 & 22.89 & 199.13 & 222.02 & 40.72 & 8.00 & 24.44 & 205.67 & 230.11 \\
\hline \multirow[t]{6}{*}{ Super X } & AG 1 & 42.50 & 6.33 & 11.16 & 108.63 & 119.74 & 41.50 & 6.17 & 13.69 & 115.00 & 128.69 \\
\hline & AG 2 & 46.08 & 6.00 & 11.61 & 121.32 & 132.93 & 45.08 & 6.33 & 12.66 & 130.32 & 142.98 \\
\hline & AG 3 & 36.82 & 6.67 & 9.23 & 61.51 & 70.73 & 36.48 & 6.83 & 11.62 & 71.61 & 83.23 \\
\hline & Yeast 1 & 40.87 & 6.33 & 9.91 & 91.93 & 101.84 & 40.87 & 6.33 & 11.88 & 100.50 & 112.38 \\
\hline & Yeast 2 & 42.67 & 7.00 & 13.34 & 134.99 & 148.33 & 41.33 & 6.67 & 13.37 & 146.00 & 159.37 \\
\hline & Yeast 3 & 46.17 & 7.83 & 20.21 & 181.79 & 202.00 & 44.50 & 7.50 & 21.73 & 192.32 & 214.05 \\
\hline \multicolumn{2}{|c|}{ L.S.D. at 0.05} & 4.18 & NS & 10.92 & 43.79 & 49.11 & NS & NS & NS & 34.73 & 38.76 \\
\hline
\end{tabular}

\subsection{Yield and Its Quality}

\subsubsection{Effect of Varieties}

Data in Table (4) illustrated that, there were significant differences in the bulb quality (bulb diameter, neck diameter, bulbing ratio and bulb weight) and total yield between the different varieties of onion plants. Moreover, the highest bulb diameter, bulb weight and total yield of onion were produced by Super X cv. On the contrary, the lowest bulb diameter, bulb weight and yield of onion plants were recorded by using Giza $20 \mathrm{cv}$. These findings held good in both two experimental seasons. With regarding of neck diameter and bulbing ratio of onion. Results in Table (4) show that, the highest neck diameter and bulbing ratio of onion bulb were recorded by Giza $20 \mathrm{cv}$. and the lowest value of neck diameter and bulbing ratio found by super $\mathrm{X} \mathrm{cv}$. These results might be correlated with the gene action of the tested cultivars. These results are agreed with those obtained by Mostafa (1998), Mohanty (2001), Rahman et al. (2002), Leilah et al. (2003), Gomaa (2006), Haydar et al. (2007).

Table 4. Effect of two varieties of onion on the yield and bulb quality in the 2009/2010 and 2010/2011 seasons

\begin{tabular}{|c|c|c|c|c|c|c|c|c|c|c|}
\hline \multirow[t]{2}{*}{ Varieties } & \multirow{2}{*}{$\begin{array}{l}\text { Bulb } \\
\text { diameter }\end{array}$} & \multirow{2}{*}{$\begin{array}{l}\text { Neck } \\
\text { diameter }\end{array}$} & \multirow[b]{2}{*}{$\begin{array}{l}\text { Bulbing } \\
\text { ratio }\end{array}$} & \multirow[b]{2}{*}{$\begin{array}{l}\text { Bulb } \\
\text { weight }\end{array}$} & \multirow[b]{2}{*}{$\begin{array}{l}\text { Total yield } \\
\text { Ton/fed. }\end{array}$} & \multirow{2}{*}{$\begin{array}{l}\text { Bulb } \\
\text { diameter }\end{array}$} & \multirow{2}{*}{$\begin{array}{l}\text { Neck } \\
\text { diameter }\end{array}$} & \multirow[b]{2}{*}{$\begin{array}{l}\text { Bulbing } \\
\text { ratio }\end{array}$} & \multirow[b]{2}{*}{$\begin{array}{l}\text { Bulb } \\
\text { weight }\end{array}$} & \multirow[b]{2}{*}{$\begin{array}{l}\text { Total yield } \\
\text { Ton/fed. }\end{array}$} \\
\hline & & & & & & & & & & \\
\hline Giza 20 & 5.72 & 2.14 & 0.37 & 100.60 & 10.84 & 5.69 & 2.28 & 0.39 & 108.34 & 11.03 \\
\hline Super X & 6.00 & 1.18 & 0.20 & 123.12 & 11.91 & 5.94 & 1.31 & 0.23 & 132.28 & 12.00 \\
\hline L.S.D at 0.05 & 0.26 & 0.15 & 0.03 & 7.65 & 0.27 & 0.12 & 0.15 & 0.30 & 11.49 & 0.34 \\
\hline
\end{tabular}

\subsubsection{Effect of Foliar Application}

Data presented in Table (5) show that, foliar application of EM, amino green, and yeast increased all bulb quality (bulb diameter, neck diameter, bulbing ratio and bulb weight) and total yield of onion compared with control. However, the highest bulb quality (bulb diameter, neck diameter, bulbing ratio and bulb weight) and total yield 
of onion plants was recorded by foliar application of EM at rates of $3 \mathrm{gm}$. /L. in the two seasons of study except for bulb diameter in the two seasons of study and bulb weight in the second season without any significant with foliar spray of EM at rates of $3 \mathrm{gm}$./L. On the contrary, the lowest bulb quality (bulb diameter, neck diameter, bulbing ratio and bulb weight) and total yield of onion plants was recorded by foliar spray with water (control). The superiority of bulb quality and total yield of onion plants by using EM may be attributed to microorganisms improve crop growth and yield by increasing photosynthesis, producing bioactive substances such as hormones and enzymes, controlling soil diseases and accelerating decomposition of lignin materials in the soil (Higa, 2000; Hussain et al., 2002).

Table 5. Effect of foliar application of EM-Effective microorganisms, amino green (AG) and yeast on the yield and bulb quality of onion plants in the 2009/2010 and 2010/2011 seasons

\begin{tabular}{|c|c|c|c|c|c|c|c|c|c|c|}
\hline Treatments & $\begin{array}{c}\text { Bulb } \\
\text { diameter }\end{array}$ & $\begin{array}{c}\text { Neck } \\
\text { diameter }\end{array}$ & $\begin{array}{c}\text { Bulbing } \\
\text { ratio }\end{array}$ & $\begin{array}{c}\text { Bulb } \\
\text { weight }\end{array}$ & $\begin{array}{c}\text { Total yield } \\
\text { Ton/fed. }\end{array}$ & $\begin{array}{c}\text { Bulb } \\
\text { diameter }\end{array}$ & $\begin{array}{c}\text { Neck } \\
\text { diameter }\end{array}$ & $\begin{array}{c}\text { Bulbing } \\
\text { ratio }\end{array}$ & $\begin{array}{c}\text { Bulb } \\
\text { weight }\end{array}$ & $\begin{array}{c}\text { Total yield } \\
\text { Ton/fed. }\end{array}$ \\
\hline Control & 4.33 & 0.99 & 0.24 & 45.08 & 8.08 & 4.32 & 1.08 & 0.27 & 50.95 & 8.28 \\
\hline EM 1 & 5.68 & 1.63 & 0.29 & 101.93 & 11.20 & 5.62 & 1.85 & 0.31 & 108.42 & 11.56 \\
\hline EM2 & 6.18 & 1.74 & 0.30 & 129.14 & 12.81 & 6.09 & 1.86 & 0.33 & 139.47 & 13.01 \\
\hline EM 3 & 5.69 & 2.04 & 0.36 & 156.33 & 17.06 & 5.39 & 2.14 & 0.37 & 162.74 & 15.69 \\
\hline AG 1 & 5.67 & 1.47 & 0.27 & 91.26 & 8.79 & 5.56 & 1.56 & 0.29 & 98.67 & 9.34 \\
\hline AG 2 & 6.26 & 1.63 & 0.26 & 111.86 & 12.38 & 6.22 & 1.84 & 0.28 & 120.65 & 12.59 \\
\hline AG 3 & 5.78 & 1.88 & 0.31 & 106.27 & 11.20 & 5.99 & 1.95 & 0.32 & 116.32 & 11.47 \\
\hline Yeast 1 & 5.67 & 1.63 & 0.29 & 90.46 & 8.77 & 5.51 & 1.84 & 0.31 & 98.86 & 9.08 \\
\hline Yeast 2 & 6.48 & 1.77 & 0.28 & 130.16 & 10.17 & 6.45 & 1.92 & 0.32 & 140.67 & 10.49 \\
\hline Yeast 3 & 6.83 & 1.83 & 0.28 & 156.08 & 13.29 & 7.02 & 1.95 & 0.30 & 166.35 & 13.63 \\
\hline L.S.D at0.05 & 0.68 & 0.25 & 0.04 & 30.93 & 2.46 & 0.77 & 0.27 & 0.04 & 30.92 & 1.86 \\
\hline
\end{tabular}

\subsubsection{Effect of the Interaction}

The interaction effect within varieties of onion plants and foliar application treatments on bulb quality (bulb diameter, neck diameter, bulbing ratio and bulb weight) and total yield are shown in Table (6). The obtained data reveals that, the interaction treatments significantly affected all bulb quality and total yield in the two seasons of study. These results held good in the two experimental seasons. Generally, it could be summarized that, the highest amount of bulb diameter was recorded by Super X cv. with foliar application of yeasts at a rate of 3 $\mathrm{gm} / \mathrm{L}$. On the contrary, the lowest bulb diameter recorded by Giza $20 \mathrm{cv}$. with foliar spray with water only (control). The highest neck diameter of bulb recorded by Giza $20 \mathrm{cv}$. with foliar spray AG at rates of $3 \mathrm{~cm} / \mathrm{L}$. On the contrary, the lowest values of neck diameter of bulb recorded by Super X cv. with foliar spray of water only (control). With regard of bulbing ratio. Data in Table (6) show that the highest bulbing ratio recorded when using Giza $20 \mathrm{cv}$. receiving foliar spray with EM at rates of $2 \mathrm{~cm} / \mathrm{L}$. On the contrary, the lowest amount of bulbing ratio recorded by using Super X cv. receiving foliar spray of water only (control) in the first season and by Super $\mathrm{X} \mathrm{cv}$. receiving foliar spray of $A G$ at rates of 1 or $2 \mathrm{~cm} / \mathrm{L}$ in the second one. With regard of bulb weight, data in Table (6) show that the highest bulb weight and total yield of onion plants were recorded by Super X cv with foliar spray of EM at a rate of $3 \mathrm{~cm} / \mathrm{L}$. Whilst, the lowest amount of bulb weight and total yield of onion plants were found by using Giza $20 \mathrm{cv}$ and foliar spray with water. These results held good in the two seasons of study. 
Table 6. Effect of the interaction between varieties and foliar application of EM-Effective microorganisms, amino green (AG) and yeast on the yield and its quality of onion plants in the 2009/2010 and 2010/2011 seasons

\begin{tabular}{|c|c|c|c|c|c|c|c|c|c|c|c|}
\hline \multirow[t]{2}{*}{ Varieties } & \multirow[t]{2}{*}{ Treatments } & \multirow{2}{*}{$\begin{array}{l}\text { Bulb } \\
\text { diameter }\end{array}$} & \multirow{2}{*}{$\begin{array}{l}\text { Neck } \\
\text { diameter }\end{array}$} & \multirow[b]{2}{*}{$\begin{array}{l}\text { Bulbing } \\
\text { ratio }\end{array}$} & \multirow[b]{2}{*}{$\begin{array}{l}\text { Bulb } \\
\text { weight }\end{array}$} & \multirow[b]{2}{*}{$\begin{array}{l}\text { Total yield } \\
\text { Ton/fed }\end{array}$} & \multirow{2}{*}{$\begin{array}{l}\text { Bulb } \\
\text { diameter }\end{array}$} & \multirow{2}{*}{$\begin{array}{l}\text { Neck } \\
\text { diameter }\end{array}$} & \multirow[b]{2}{*}{$\begin{array}{l}\text { Bulbing } \\
\text { ratio }\end{array}$} & \multirow[b]{2}{*}{$\begin{array}{l}\text { Bulb } \\
\text { weight }\end{array}$} & \multirow[b]{2}{*}{$\begin{array}{l}\text { Total yield } \\
\text { Ton/fed. }\end{array}$} \\
\hline & & & & & & & & & & & \\
\hline \multirow{10}{*}{ Giza 20} & Control & 3.67 & 1.20 & 0.33 & 27.93 & 6.65 & 3.73 & 1.30 & 0.35 & 28.46 & 6.82 \\
\hline & EM 1 & 5.53 & 2.17 & 0.39 & 102.76 & 10.23 & 5.57 & 2.37 & 0.40 & 107.43 & 10.40 \\
\hline & EM2 & 5.20 & 2.25 & 0.43 & 89.75 & 12.25 & 5.23 & 2.25 & 0.45 & 100.42 & 12.40 \\
\hline & EM 3 & 6.47 & 2.17 & 0.34 & 113.53 & 13.59 & 6.27 & 2.30 & 0.35 & 119.82 & 13.89 \\
\hline & AG 1 & 5.15 & 1.97 & 0.38 & 73.88 & 9.11 & 5.10 & 2.05 & 0.39 & 82.34 & 9.34 \\
\hline & AG 2 & 6.12 & 2.25 & 0.37 & 102.40 & 14.86 & 5.93 & 2.57 & 0.38 & 110.48 & 14.74 \\
\hline & AG 3 & 4.78 & 2.68 & 0.39 & 151.03 & 10.64 & 6.93 & 2.82 & 0.41 & 161.03 & 10.86 \\
\hline & Yeast 1 & 5.57 & 2.08 & 0.37 & 88.99 & 9.22 & 5.46 & 2.22 & 0.39 & 97.21 & 9.92 \\
\hline & Yeast 2 & 6.42 & 2.27 & 0.36 & 125.34 & 10.08 & 6.48 & 2.50 & 0.37 & 135.34 & 10.40 \\
\hline & Yeast 3 & 6.25 & 2.35 & 0.38 & 130.37 & 11.70 & 6.30 & 2.47 & 0.39 & 140.37 & 11.99 \\
\hline \multirow{10}{*}{ Super X } & Control & 5.00 & 0.78 & 0.16 & 62.24 & 9.52 & 4.91 & 0.85 & 0.19 & 73.44 & 9.73 \\
\hline & EM 1 & 5.83 & 1.10 & 0.19 & 101.10 & 12.17 & 5.67 & 1.34 & 0.22 & 109.40 & 12.73 \\
\hline & EM2 & 7.15 & 1.23 & 0.17 & 168.52 & 13.37 & 6.94 & 1.97 & 0.20 & 178.52 & 13.62 \\
\hline & EM 3 & 4.92 & 1.92 & 0.39 & 199.13 & 19.53 & 4.52 & 1.98 & 0.39 & 205.67 & 17.48 \\
\hline & AG 1 & 6.18 & 0.97 & 0.16 & 108.63 & 8.47 & 6.02 & 1.07 & 0.18 & 115.00 & 9.33 \\
\hline & AG 2 & 6.40 & 1.00 & 0.16 & 121.32 & 9.89 & 6.51 & 1.12 & 0.18 & 130.32 & 10.44 \\
\hline & AG 3 & 4.78 & 1.08 & 0.23 & 61.51 & 11.76 & 5.13 & 1.08 & 0.24 & 71.61 & 12.08 \\
\hline & Yeast 1 & 5.77 & 1.17 & 0.20 & 91.93 & 8.33 & 5.56 & 1.47 & 0.23 & 100.50 & 8.74 \\
\hline & Yeast 2 & 6.55 & 1.27 & 0.20 & 134.99 & 10.27 & 4.42 & 1.33 & 0.22 & 146.00 & 10.57 \\
\hline & Yeast 3 & 7.40 & 1.32 & 0.18 & 181.79 & 14.82 & 7.73 & 1.43 & 0.21 & 192.32 & 15.26 \\
\hline \multicolumn{2}{|c|}{ L.S.D. at 0.05} & 0.96 & 0.36 & 0.36 & 43.75 & 3.48 & 1.1 & 0.38 & 0.06 & 34.73 & 2.63 \\
\hline
\end{tabular}

\subsection{Chemical Contents}

\subsubsection{Effect of Varieties}

Chemical contents of onion plant expressed as T.S.S, N, P and K\% were statistically affected by varieties of onion plants (Figure 1). The differences resulting by the varieties reached the level of significant at all vegetative growth characters in the two seasons of study except for $\mathrm{N} \%$ in the two seasons of study. Furthermore, the highest values in as T.S.S, N, P and K\% were obtained by the Giza $20 \mathrm{cv}$. On the other hand, the lowest values were recorded by Super X cv. These results were true in the two seasons of study. These results were coincided with those reported by Gomaa (2006) and Haydaret al. (2007).

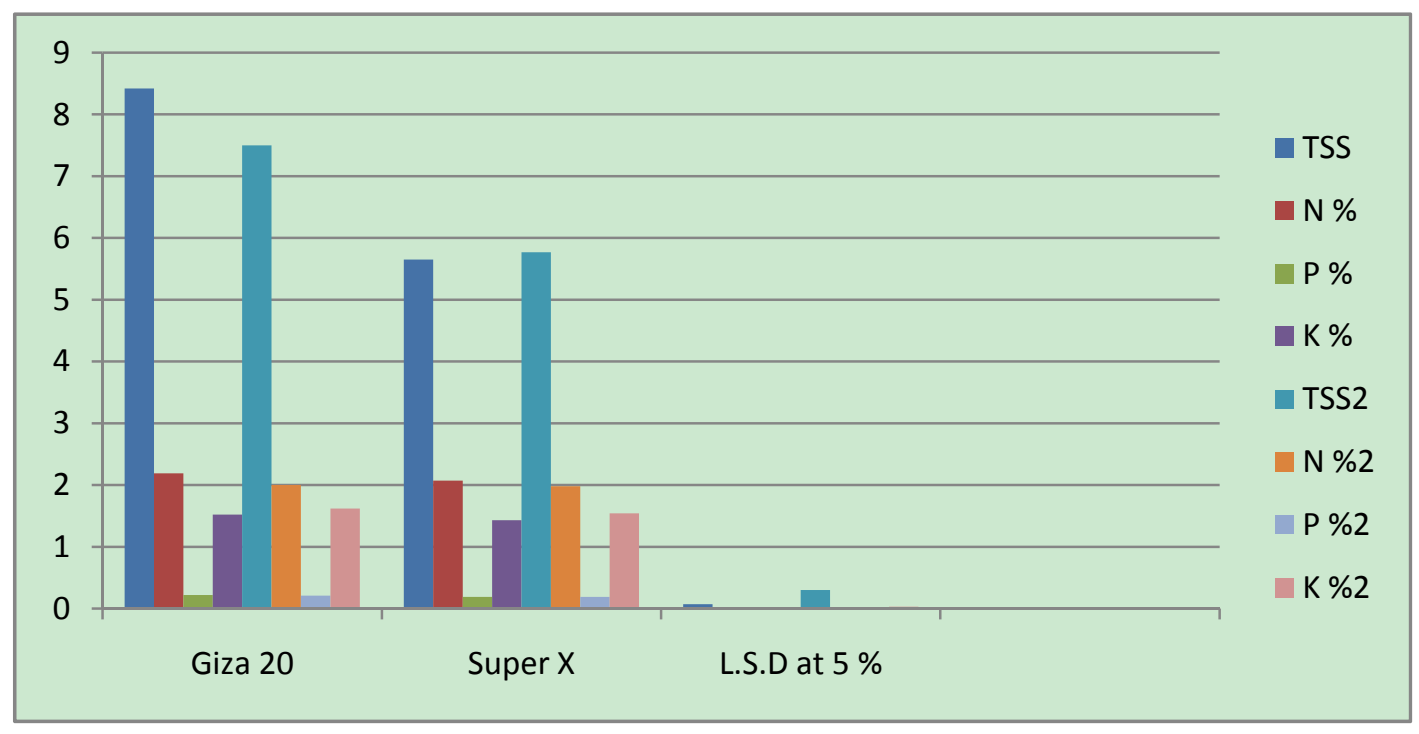

Figure 1. Effect of two varieties of onion on the T.S.S, N, P and K\% in the 2009/2010 and 2010/2011 seasons 


\subsubsection{Effect of Foliar Application}

Data in Table (7) show clearly that foliar application of EM, amino green and yeast had a significant effect on the chemical content characterizes of onion tissues in the two seasons of study. Generally, it could be concluded that, the highest values of T.S.S was recorded by using yeast at rates of $3 \mathrm{gm}$. /L. compared with other treatments. On the contrary, the lowest value of T.S.S was recorded by control plants (foliar spray with water). These findings were true in both seasons. With regards of $\mathrm{N}, \mathrm{P}$ and $\mathrm{K} \%$, results in Table (7) demonstrated that, the highest values of $\mathrm{N}, \mathrm{P}$ and $\mathrm{K} \%$ were recorded by using foliar application of AG with different rates compared of other treatments. On the other hand, the lowest value of N, P and K \% were recorded by control plants (foliar spray with water). These findings were true in both seasons of study.

Table 7. Effect of foliar application of EM-Effective microorganisms", amino green (AG) and yeast on T.S.S, N,P and K\% of onion tissues in the 2009/2010 and 2010/2011 seasons

\begin{tabular}{lllllllll}
\hline Treatments & T.S.S & $\mathrm{N} \%$ & $\mathrm{P} \%$ & $\mathrm{~K} \%$ & $\mathrm{~T} . \mathrm{S} . \mathrm{S}$ & $\mathrm{N} \%$ & $\mathrm{P} \%$ & $\mathrm{~K} \%$ \\
\hline Control & 6.47 & 1.79 & 0.15 & 1.25 & 6.03 & 1.70 & 0.14 & 1.35 \\
EM 1 & 6.88 & 1.90 & 0.19 & 1.32 & 6.50 & 1.77 & 0.18 & 1.42 \\
EM2 & 7.03 & 2.08 & 0.22 & 1.39 & 6.67 & 1.97 & 0.21 & 1.47 \\
EM 3 & 7.40 & 2.30 & 0.23 & 1.46 & 6.75 & 1.79 & 0.22 & 1.61 \\
AG 1 & 6.83 & 2.70 & 0.18 & 1.48 & 6.38 & 2.27 & 0.17 & 1.58 \\
AG 2 & 7.13 & 2.18 & 0.20 & 1.59 & 6.67 & 2.04 & 0.20 & 1.66 \\
AG 3 & 7.02 & 2.28 & 0.32 & 1.68 & 6.92 & 2.16 & 0.22 & 1.79 \\
Yeast 1 & 7.00 & 2.06 & 0.21 & 1.49 & 6.57 & 1.93 & 0.21 & 1.57 \\
Yeast 2 & 7.13 & 2.17 & 0.23 & 1.54 & 6.85 & 2.13 & 0.22 & 1.65 \\
Yeast 3 & 7.42 & 2.22 & 0.24 & 1.59 & 7.05 & 2.12 & 0.23 & 1.69 \\
L.S.D at0.05 & 0.22 & 0.06 & 0.01 & 0.04 & 0.26 & 0.12 & 0.01 & 0.04 \\
\hline
\end{tabular}

This superiority might be due to that amino green compound contains many amino acids as well as some growth regulators and vitamins which stimulate and enhance the metabolism processes in plant tissues. Whereas, the previous studies have proved that, amino acids, can directly or indirectly influenc the physiological activities of the plants (Ei-Shabase et al., 2005; Awad et al., 2007; Al-Said \& Kamal, 2008; Faten et al., 2010; Shaheen et al., 2010).

\subsubsection{Effect of the Interaction}

The interaction effect within varieties of onion plants and foliar application treatments on T.S.S, N, P and K \% are shown in Table 8 . The obtained data reveals that, the interaction treatments significantly affected T.S.S, P\% in the two seasons of study and $\mathrm{K} \%$ in the second season only. These results held good in the two experimental seasons. Generally, it could be summarized that, the highest amount of T.S.S, N, P and K \% were recorded by using Giza $20 \mathrm{cv}$. with foliar application of EM and AG compared with foliar spray of yeast and control treatment (foliar spray of water). On the contrary, the lowest T.S.S, N, P and K \% were recorded by Super X cv. with foliar spray with water only (control). 
Table 8. Effect of the interaction between varieties and foliar application of EM "Effective microorganisms", amino green (AG) and yeast on the T.S.S, N,P and K\% of onion tissues in the 2009/2010 and 2010/2011 seasons

\begin{tabular}{llllllllll}
\hline Varieties & Treatments & T.S.S & N \% & P \% & K \% & T.S.S & N \% & P \% & K \% \\
\cline { 2 - 8 } & Control & 7.60 & 1.84 & 0.17 & 1.31 & 6.67 & 1.76 & 0.15 & 1.41 \\
& EM 1 & 8.23 & 1.95 & 0.21 & 1.39 & 7.43 & 1.81 & 0.20 & 1.48 \\
& EM2 & 8.63 & 2.09 & 0.26 & 1.43 & 7.80 & 1.95 & 0.24 & 1.51 \\
Giza 20 & EM 3 & 9.23 & 2.40 & 0.25 & 1.48 & 7.87 & 2.34 & 0.24 & 1.59 \\
& AG 1 & 8.13 & 2.21 & 0.18 & 1.53 & 7.17 & 1.76 & 0.18 & 1.62 \\
& AG 2 & 8.33 & 2.26 & 0.21 & 1.63 & 7.47 & 2.08 & 0.20 & 1.69 \\
& AG 3 & 8.37 & 2.34 & 0.23 & 1.76 & 7.83 & 2.13 & 0.23 & 1.87 \\
& Yeast 1 & 8.37 & 2.14 & 0.22 & 1.51 & 7.37 & 1.93 & 0.21 & 1.59 \\
& Yeast 2 & 8.50 & 2.15 & 0.24 & 1.57 & 7.63 & 2.13 & 0.23 & 1.69 \\
& Yeast 3 & 8.77 & 2.20 & 0.25 & 1.63 & 7.80 & 2.13 & 0.24 & 1.79 \\
\hline Control & 5.33 & 1.74 & 0.13 & 1.19 & 5.40 & 1.65 & 0.12 & 1.29 \\
& EM 1 & 5.53 & 1.85 & 0.16 & 1.24 & 5.57 & 1.74 & 0.16 & 1.35 \\
& EM2 & 5.43 & 2.07 & 0.18 & 1.35 & 5.53 & 1.98 & 0.18 & 1.44 \\
& EM 3 & 5.57 & 2.20 & 0.20 & 1.43 & 5.63 & 2.20 & 0.20 & 1.63 \\
& AG 1 & 5.53 & 1.93 & 0.17 & 1.43 & 5.60 & 1.83 & 0.17 & 1.55 \\
& AG 2 & 5.93 & 2.10 & 0.20 & 1.54 & 5.87 & 2.00 & 0.19 & 1.62 \\
Superyyyyyyyyyyyyy X & AG 3 & 5.67 & 2.23 & 0.22 & 1.60 & 6.00 & 2.19 & 0.21 & 1.70 \\
& Yeast 1 & 5.63 & 1.97 & 0.20 & 1.46 & 5.77 & 1.94 & 0.20 & 1.55 \\
& Yeast 2 & 5.77 & 2.19 & 0.21 & 1.50 & 6.07 & 2.13 & 0.21 & 1.61 \\
& Yeast 3 & 8.07 & 2.30 & 0.23 & 1.54 & 6.30 & 2.10 & 0.22 & 1.63 \\
\hline L.S.D. at 0.05 & 0.30 & NS & 0.02 & NS & 0.37 & NS & 0.02 & 0.06 \\
\hline
\end{tabular}

\subsection{Trace Element Content}

\subsubsection{Effect of Varieties}

Trace element content of onion tissues expressed as $\mathrm{Fe}, \mathrm{Cu}, \mathrm{Zn}$ and $\mathrm{Mn}$ were affected by varieties of onion plants (Figure 2). The differences resulting by the varieties reached the level of significant at $\mathrm{Fe}, \mathrm{Cu}$ and $\mathrm{Zn}$ in the first season and $\mathrm{Zn}$ and $\mathrm{Mn}$ in the second one. Moreover, the highest values of all trace elements content were obtained by the Giza $20 \mathrm{cv}$. except for $\mathrm{Mn}$ in the first season and Fe in the second season, the highest amount was recorded by Super X cv. On the other hand, the lowest values were recorded by Super X cv. except for Mn and Fe ppm in the first and second seasons, respectively. The lowest values were found by Giza $20 \mathrm{cv}$. These results were true in the true seasons of study. These results were coincided with those reported by Gomaa (2006) and Haydar et al. (2007).

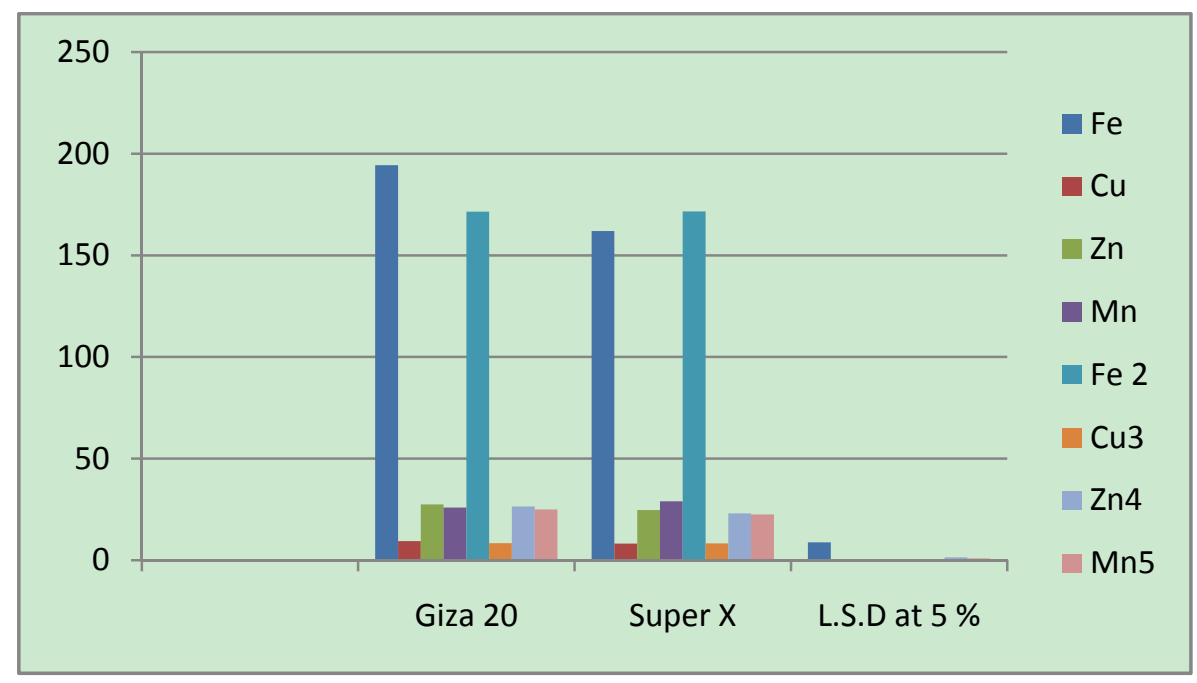

Figure 2. Effect of two varieties of onion on the Fe, Cu, Zn and Mn ppm in the 2009/2010 and 2010/2011 seasons 


\subsubsection{Effect of Foliar Application}

Data in Table (9) show clearly that foliar application of EM, amino green and yeast had a significant effect on the trace elements content of onion tissues in the two seasons of study except for $\mathrm{Mn} \mathrm{ppm}$ in the first season failed to significant effect. Generally, it could be concluded that, the highest values of trace elements content (Fe, $\mathrm{Zn}$ and $\mathrm{Mn}$ ) were recorded by using foliar application of $\mathrm{AG}$ at rates of $3 \mathrm{~cm} / \mathrm{L}$. compared with other treatments. Whilst, the highest amount of $\mathrm{Cu}$ ppm was recorded by foliar spray of yeast at a rate of $3 \mathrm{bm} . / \mathrm{L}$. These results were true in the two seasons of study. On the contrary, the lowest value of all trace element measures were recorded by control plants (foliar spray with water). These findings were true in both seasons. These results may be due to the content of macro and micro elements of the dry yeast and amino green compound. El-Fouly 1983 reported that, foliar application of microelements is highly recommended under Egyptian conditions. In view of the fact the soil $\mathrm{pH}$ exceeds 7.5 and sometimes even 8.5 some areas show high $\mathrm{CaCO}_{3}$ contents which among other factors; make soil application of micronutrients more costly and unpractical. The trends of obtained results are in good accordance of the previous investigators such as (Ei-Shabase et al., 2005; Awad et al., 2007; Al-Said \& Kamal, 2008; Faten et al., 2010).

Table 9. Effect of foliar application of EM "Effective microorganisms", amino green (AG) and yeast on $\mathrm{Fe}, \mathrm{Cu}$, $\mathrm{Zn}$ and Mn ppm of onion tissues in the 2009/2010 and 2010/2011 seasons

\begin{tabular}{lllllllll}
\hline Treatments & $\begin{array}{l}\mathrm{Fe} \\
\mathrm{ppm}\end{array}$ & $\begin{array}{l}\mathrm{Cu} \\
\mathrm{ppm}\end{array}$ & $\begin{array}{l}\mathrm{Zn} \\
\mathrm{ppm}\end{array}$ & $\begin{array}{l}\mathrm{Mn} \\
\mathrm{ppm}\end{array}$ & $\begin{array}{l}\mathrm{Fe} \\
\mathrm{ppm}\end{array}$ & $\begin{array}{l}\mathrm{Cu} \\
\mathrm{ppm}\end{array}$ & $\begin{array}{l}\mathrm{Zn} \\
\mathrm{ppm}\end{array}$ & $\begin{array}{l}\mathrm{Mn} \\
\mathrm{ppm}\end{array}$ \\
\hline Control & 137.65 & 7.98 & 23.90 & 20.41 & 143.67 & 7.50 & 22.88 & 19.87 \\
EM 1 & 154.75 & 8.60 & 25.32 & 22.78 & 150.77 & 7.92 & 24.30 & 21.71 \\
EM2 & 166.30 & 8.80 & 26.01 & 24.06 & 157.06 & 8.56 & 24.95 & 22.97 \\
EM 3 & 173.83 & 9.17 & 26.86 & 25.65 & 167.67 & 8.71 & 25.91 & 24.55 \\
AG 1 & 171.72 & 8.61 & 26.11 & 24.72 & 167.78 & 8.07 & 25.29 & 23.70 \\
AG 2 & 186.67 & 8.77 & 27.42 & 22.47 & 180.67 & 8.48 & 26.39 & 23.94 \\
AG 3 & 215.83 & 8.93 & 28.21 & 28.08 & 200.00 & 8.61 & 26.97 & 27.17 \\
Yeast 1 & 180.12 & 8.68 & 24.89 & 24.40 & 177.16 & 8.23 & 22.37 & 23.63 \\
Yeast 2 & 194.00 & 9.22 & 25.70 & 26.59 & 184.00 & 8.53 & 23.11 & 25.25 \\
Yeast 3 & 200.50 & 9.59 & 26.62 & 25.61 & 186.69 & 9.05 & 25.74 & 24.83 \\
L.S.D at 0.05 & 11.82 & 0.28 & 0.83 & NS & 7.42 & 0.21 & 2.05 & 2.35 \\
\hline
\end{tabular}

\subsubsection{Effect of the Interaction}

The interaction effect within varieties of onion plants and foliar application treatments on trace element contents $(\mathrm{Fe}, \mathrm{Cu}, \mathrm{Zn}$ and $\mathrm{Mn})$ are shown in Table 10. The obtained data reveals that, the interaction treatments had no significantly affected of all trace element content except for $\mathrm{Fe}$ in the first season. These results held good in the two experimental seasons. Generally, it could be summarized that, the highest amount of Fe ppm was recorded by using Giza $20 \mathrm{cv}$. with foliar application of $A G$ at a rate of $3 \mathrm{~cm} / \mathrm{L}$ in the first season and by Super $\mathrm{X} \mathrm{cv}$. with foliar spray of $\mathrm{AG}$ at a rate of $3 \mathrm{~cm} / \mathrm{L}$ in the second one. With regard of $\mathrm{Cu} \mathrm{ppm}$, the highest amount of $\mathrm{Cu} \mathrm{ppm}$ was recorded by using Giza $20 \mathrm{cv}$. with foliar application of yeast at a rate of $3 \mathrm{gm}$. /L in the first season and by Super X cv with foliar spray of yeast at a rate of $3 \mathrm{gm}$. /L in the second season. Meanwhile, the highest amount of $\mathrm{Zn}$ and $\mathrm{Mn}$ ppm were recorded by using Giza $20 \mathrm{cv}$. with foliar spray of $\mathrm{AG}$ at a rate of $3 \mathrm{~cm} / \mathrm{L}$. These findings were true in both seasons. On the contrary, the lowest amounts of all trace elements were recorded by Super X $\mathrm{cv}$. with foliar spray with water only (control) except for $\mathrm{Fe}$ and $\mathrm{Cu}$ in the second season, the lowest amount was found by Giza $20 \mathrm{cv}$. with foliar spray with water only (control). 
Table 10. Effect of the interaction between varieties and foliar application of EM "Effective microorganisms", amino green (AG) and yeast on the $\mathrm{Fe}, \mathrm{Cu}, \mathrm{Zn}$ and $\mathrm{Mn}$ ppm of onion tissues in the 2009/2010 and 2010/2011 seasons

\begin{tabular}{|c|c|c|c|c|c|c|c|c|c|}
\hline \multirow[t]{5}{*}{ Varieties } & Treatments & $\begin{array}{l}\mathrm{Fe} \\
\mathrm{ppm}\end{array}$ & $\begin{array}{l}\mathrm{Cu} \\
\mathrm{ppm}\end{array}$ & $\begin{array}{l}\mathrm{Zn} \\
\mathrm{ppm}\end{array}$ & $\begin{array}{l}\mathrm{Mn} \\
\mathrm{ppm}\end{array}$ & $\begin{array}{l}\mathrm{Fe} \\
\mathrm{ppm}\end{array}$ & $\begin{array}{l}\mathrm{Cu} \\
\mathrm{ppm}\end{array}$ & $\begin{array}{l}\mathrm{Zn} \\
\mathrm{ppm}\end{array}$ & $\begin{array}{l}\text { Mn } \\
\text { ppm }\end{array}$ \\
\hline & Control & 141.69 & 8.44 & 25.43 & 21.23 & 143.70 & 7.35 & 24.39 & 20.77 \\
\hline & EM 1 & 169.10 & 9.39 & 26.80 & 23.78 & 150.55 & 8.02 & 25.85 & 22.44 \\
\hline & EM2 & 184.93 & 9.38 & 27.21 & 24.89 & 156.67 & 8.61 & 26.24 & 23.76 \\
\hline & EM 3 & 189.33 & 9.72 & 28.14 & 26.97 & 168.33 & 8.75 & 27.17 & 25.87 \\
\hline \multirow[t]{10}{*}{ Giza 20} & AG 1 & 184.33 & 9.26 & 27.22 & 25.80 & 168.00 & 8.07 & 26.65 & 24.91 \\
\hline & AG 2 & 200.33 & 9.25 & 28.47 & 26.77 & 181.33 & 8.49 & 27.48 & 25.74 \\
\hline & AG 3 & 244.33 & 9.38 & 29.22 & 28.58 & 196.00 & 8.61 & 27.66 & 27.84 \\
\hline & Yeast 1 & 192.67 & 9.33 & 26.62 & 25.17 & 177.21 & 8.32 & 25.79 & 24.28 \\
\hline & Yeast 2 & 213.00 & 10.10 & 27.48 & 27.87 & 184.67 & 8.54 & 26.59 & 26.35 \\
\hline & Yeast 3 & 223.00 & 10.29 & 28.14 & 28.26 & 188.38 & 9.00 & 26.92 & 27.73 \\
\hline & Control & 133.60 & 7.51 & 22.36 & 19.59 & 143.63 & 7.65 & 21.36 & 18.98 \\
\hline & EM 1 & 140.39 & 7.81 & 23.84 & 21.79 & 150.99 & 7.82 & 22.75 & 20.97 \\
\hline & EM2 & 158.33 & 8.21 & 24.82 & 23.22 & 157.45 & 8.51 & 23.65 & 22.19 \\
\hline & EM 3 & 159.33 & 8.61 & 25.59 & 24.32 & 167.00 & 8.68 & 24.95 & 23.22 \\
\hline \multirow[t]{6}{*}{ Super X } & AG 1 & 159.11 & 7.95 & 24.99 & 23.63 & 167.55 & 8.07 & 23.93 & 22.99 \\
\hline & AG 2 & 173.00 & 8.29 & 26.37 & 78.17 & 180.00 & 8.40 & 25.30 & 22.15 \\
\hline & AG 3 & 187.33 & 8.48 & 27.20 & 27.59 & 204.00 & 8.61 & 26.28 & 26.48 \\
\hline & Yeast 1 & 167.58 & 8.03 & 23.15 & 23.63 & 177.11 & 8.15 & 18.96 & 22.98 \\
\hline & Yeast 2 & 175.00 & 8.34 & 23.15 & 25.30 & 183.33 & 8.51 & 19.63 & 24.16 \\
\hline & Yeast 3 & 178.00 & 8.88 & 23.92 & 22.97 & 185.00 & 9.09 & 24.55 & 21.94 \\
\hline \multicolumn{2}{|c|}{ L.S.D. at 0.05} & 10.72 & NS & NS & NS & NS & NS & NS & NS \\
\hline
\end{tabular}

\section{Conclusion}

It can be recommended that all applied bio-stimulants have a positive and growth promoting effects on two cultivar of onion plants by providing supplemental doses of bio-stimulants "yeast, EM and amino acids".

Generally, it can be concluded that, using Super X cv. with foliar spraying of EM gives highest amount of growth, yield and quality of onion plants.

\section{Acknowledgment}

The authors would express their thanks for all fruitful efforts presented and supported by Postdoctoral Program for African Researchers of China-Africa Science and Technology Partnership Program (CASTEP).

\section{References}

A. O. A. C. (1990). Official Methods of Analysis.15th ed., Washington, D. C., Association of Official Analytical Chemists.

Abou El-Nasr, M. E., El-Shabrawy, R. A, \& Abd El-Rahman, M. M. (2001). Effect of Bread yeast application and some nutrient elements on squash (Cucurbita pepo L.) plant growth, yield and fruit quality under conditions of the early summer planting. J. Agric. Sci. Mansoura Univ., 26(7), 4451-4464.

Ahmed, F. F., Aki, A. M., El-Morsy, F. M., \& Raggab, M. A. (1997). The beneficial effect of biofertilizer on red roomy grape vine (Vita vinfera L). the effect on growth and vine nutritional status. Annals of Agric. Sci, Moshtohor, 35(1), 489-495. 
Al-Said, M. A., \& Kamal, A. M. (2008). Effect of foliar spray with folic acid and some amino acids on flowering, yield and quality of sweet pepper. J. Agri. Sci., Mansoura Univ., 33(10), 7403-7412.

Attoa, G. E., Wahba, H. E, \& Frahat, A. A. (2002). Effect of some amino acids and sulpher fertilizers on growth and chemical composition of Iberisarmara L. Plant Egypt. J. Hort., 29(1), 17-37.

Awad, El-M. M., Abd El-Hameed, A. M., \& El-Aimin, Z. A. (2007). Effect of Glycine, Lysine and nitrogen fertilizer rates on growth, yield and chemical composition of potato. J. Agric. Sci. Mansoura Univ., 32(10), 8541-8551.

Chaliakhyan, M. Kh. (1957). Effect of vitamins on growth and development of plants.DoklyAkad. Nauk. SSSK, $111,894-897$.

Chapman, H. D., \& Pratt, P. F. (1961). Methods of analysis for soil, plant and water. California Univ. USA.

Chapman, H. D., \& Pratt, P. F. (1982). Methods of Plant Analysis, I. Methods of Analysis for Soil, Plant and Water. California, Chapman Publishers, Riverside.

Cottenie, A. L. (1980). Soils and plant testing as a basis of fertilizer recommendation. FAO Soil Bull., No. 3812.

Daiss, N., Lobo, M. G., Socorro, R., Bruckner, U., Heller, J., \& Gonzaler, M. (2008). The effect of three organic pre-harvest treatments on Swiss chard (Beta vulgaris L. var. Cycla L.) quality. Eur. Food Res. Technol., 226, 345-353. http://dx.doi.org/10.1007/s00217-006-0543-2

Diaz, T. R. (1994). Evaluation of 12 onion cultivars for growing in the Quibor depression. Venezuela Agronomia Tropical (Maracay), 44, 693-699.

El-Fouly, M. M. (1983). Micronutrients in arid and semiarid areas: Levels in soil and plants for fertilizers, with particular reference to Egypt. Proc. $17^{\text {th }}$ codoguium international potash Inst, Kakat and Marrakesh/ Morocco 11.

El-Ghamriny, E. A., Arisha, H. M. E, \& Nour, K. A. (1999). Studies in tomato flowering fruit set,yield and quality in summer seasons. 1- Spraying with thiamine, ascorbic acid and yeast. Zagazig. J. Agric. Rec., 26(5), 1345-1364.

El-Shabasi, M. S., Mohamed, S. M,, \& Mahfouz, S. A. (2005). Effect of foliar spray with some amino acids on growth, yield and chemical composition of garlic plants. The $6^{\text {th }}$ Arabian Conf. for Hort., Ismailia, Egypt.

El-Tohamy, W. A., El-Abagy, H. M., \& El-Greadly, N. H. M. (2008). Studies on the Effect of putrescine, yeast and vitamin $\mathrm{C}$ on growth, yield and physiological Responses of eggplant (Salanum melongena L.) under sandy soil conditions. Australian Journal of Basic and Applied. Science, 2(2), 296-300.

El-Tohamy, W. I. A., \& El-Greadly, N. H. M. (2007). Physiological responses, growth, yield and quality of Snap bean in response to foliar application of yeast, vitamin E and Zinc under sandy soil conditions. Australian Journal of Basic and Applied Sciences, 1(3), 294-299.

Faten, S. Abd El-Aal, Shaheen, A. M., Ahmed, A. A., \& Asmaa, R. M. (2010). The effect of foliar application of urea and amino acids mixtures as antioxidants on the growth and yield and characteristics of squash. Res. $J$. Agric. Biol. Sci., 6(5), 583-588.

Fawzy, Z. F. (2007). Increasing productivity of head lettuce by foliar spraying of some bio and organic compounds. Egypt. J. Appl. Sci., 22(10A), 237-247.

Fawzy, Z. F., El-Bassiony, A. M., Behairy, A. G., \& Helmy, Y. I. (2010). Effect of foliar spraying by some bio and organic compounds on growth, yield and chemical composition of Snap bean plants. Journal of Applied Sciences Research, 6(12), 2269-2274.

Ghoname, A. A., El-Nemr, M. A., Abdel-Mawgoud, A. M. R., \& El-Tohamy, W. A. (2010). Enhancement of Sweet pepper crop growth and production by application of biological, organic and nutritional solutions. Research Journal of Agriculture and Biological Sciences, 6(3), 349-355.

Glick, B. R. (1995). The enhancement of plant growth by free living bacteria. Cand. J. Microbiology, 41, 109-117. http://dx.doi.org/10.1139/m95-015

Gomaa, A. M., Moawad, S. S., Ebadah, I. M. A., \& Salim, H. (2005). Application of bio-organic farming and its influence on certain pests infestation, growth and productivity of potato plants. Journal of Applied Sciences Research, 1(2), 205-211.

Gomaa, M. G. M. (2006). Genetic studies on some economic characters in onion (Allium cepa, L). Ph.D. Thesis, Fac. Agric. El-Minia, Egypt. 
Gomez, K. A., Gomez.A. A (1984). Statistical procedures for agriculture Research. Second Ed. Willey inter Science, 357-423.

Goyal, S., \& Khuller, G. K. (1992). Phospholipid composition and subcellular distribution in yeast and mycelial forms of Candida allicans. Sournal of medical and veterinary mycology, 30(5), 355-362.

Haydar, A., Sharker, N., Ahmed., M. B., Hannan, M. M., Razvy, M. A., Hassaini, M., ... Karim, R. (2007). Genetic variability and interrelationship in onion (Allium cepa, L). Middle-East J. Scientific. Rec, 2(3-4), 132-134.

Higa, T. (2000). What is EM Technology? EM world J., 1, 1-6.

Higa. (1991). Effective microorganisms: A biotechnology for mankind. P.7-14. In J. F. Parr, S. B. Hornick, and C. E. Whitman (ed.) Proceedings of the First International Conference on Kyusei Nature Farming. U.S. Department of Agriculture, Washington. D.C., USA.

Hussain, T., Anjum, A. D., Tahir, J. (2002). Technology of beneficial microorganisms. Nature farming. Environ., $3,1-14$.

Hussain, W., \& Khalaf, L. (2007). Effect of foliar spraying with yeast solution on growth and yield of potato plant cv. desiree. Retrieved from: www.tropentage.de/2007/abstracts/links/khalaf. FPRAXY 90

Javaid, A. (2006). Foliar application of effective microorganisms on peas an alternative fertilizer. Agron. Sustain. Dev., 26, 257-262. http://dx.doi.org/10.1051/agro:2006024

Javaid, A. (2009). Growth, nodulation and yield of black gram (Vigna mungo, L. Hepper) as influenced by biofertilizers and soil amendments. Afr. J. Biotechnol., 8, 5711-5717.

Javaid, A., \& Nasir Mahmood. (2010). Growth, nodulation and yield response of soybean to biofertilizers and organic manures. P. J. Bot., 42(2), 863-871.

Kengo, Y., \& Hui-lian, X. (2000). Properties and applications of an organic fertilizer inoculated with effective microorganisms. Journal of Crop production, 3(1), 255-268.

Khaliq, A., Abbasi, M. K., \& Hussain, T. (2006). Effect of integrated use of organic and inorganic nutrient sources with effective microorganisms (EM) on seed cotton yield in Pakistan. Bioresour. Technol., 97, 967-972. http://dx.doi.org/10.1016/j.biortech.2005.05.002

Khedr, Z. M. A., \& Farid, S. (2002). Response of naturally virus infected tomato plants to yeast extract and phosphoric acid application. Annals of Agric. Sci. Moshtohor. Egypt, 38(2), 927-939..

Leilah, A. A., El- Kallai, S. A., Mostafa, A. K., \& Afifi, H. M. A. (2003). Performance of some local Egyptian onion. Strains under different planting dates: Scientific. J. of King Faisal Univ.- Basic and Applied Sciences, 4(1), 119-136.

Mohanty, B. K. (2001). Genetic variability, interrelationship and path analysis in onion. J. Tropical Agric., 39, 17-20.

Mona, M., Kabeel, S. M. A., \& Fayza, M. A. (2005). Effect of organic and biofertilizer on growth, yield and fruit quality of cucumber grown under clear polyethelene low tunnels. J. Agric. Sci. Mansoura Univ., 30(5), 2827-2841.

Mostafa, A. K. (1998). Yield and qualities of Giza 20 onion bulb as affected by transplanting date and source of seed. J. Agric. Sci. Mansoura Univ., 23(1), 61-69.

N. R. P. (1977). Nutrient Requirements of Domestic Animals, (Rabbits), No. $17^{\text {th }}$ Rev. Ed., p.16-26. National Academy of Science, Washington, D. C.

Nishio, M. (1996). Microbial Fertilizers in Japan. Food and Fertilizer Technology Center. p. 12.

Pham, D. T. (2004). FNCA Biofertilizer Newsletter. Japan Atomic Industrial Forum, Inc. 4, 1-8.

Rahman, M. A., Saha, S. R., Salam, M. A., Masun, A. S. M. H., \& Chowdhury, S. S. (2002). Correlation and path coefficient analysis in onion (Allium cepa, L). J. of Biological Sci., 2(8), 533-534.

Sanaa, A. M. Z., Ibrahim, S. I., \& Eldeen, H. A. M. S. (2001). The effect of naphthalene acetic acid (NAA). Salicylic acid on growth, fruit setting, yield and some correlated components in dry bean. Annals of Agric. Sci. Cairo, 46(2), 451-463. 
Shaheen, A. M., Fatma, A. R., Hoda, A. M., Habib, A. E., \& Baky, M. M. H. (2010). Nitrogen soil dressing and foliar spraying by sugar and amino acids as affected the growth, yield and its quality of onion plant. Journal of American Science, 6(8), 420-427.

Sheng, Y. P., \& Lian, X. H. (2002). Influence of EM Bokashi on nodulation, physiological characters and yield of peanut in nature farming fields. J. Sustain. Agric., 19, $105-112$. http://dx.doi.org/10.1300/J064v19n04_10

Slviero, P., Zoniand, C., \& Frullanti, B. (2001). Efficiency of on notifying growth regulator on industrial tomatoes. Informatory Agro., 57(14), 73-75.

Yatskovskaya, P. Y., Solomko, G. E., Konoko, I. V., \& Yanchovskil, V. K. (1992). Chemical composition of protein concentrate from saccharomyces yeast molasses effect on immune response. Voprosy, pitaniya, 1, 63-67. 